UDC 378.147:811.581.11

\author{
Olha Dalte \\ Lecturer at the Department of Chinese Philology, Master of Science in Educational Technologies \\ Kyiv National Linguistic University, Kyiv, Ukraine \\ ORCID ID 0000-0001-5280-4279 \\ olha.dalte@knlu.edu.ua
}

\title{
THE IMPACT OF TECHNOLOGY-ENHANCED LEARNING ENVIRONMENT ON TEACHING CHINESE AS A SECOND LANGUAGE
}

\begin{abstract}
Due to an increased number of economic and business relationships between Ukraine and China, the number of those who learn Chinese language multiplies each year. However, the main problem is that Ukrainian educational institutions do not possess enough resources and academic staff to meet the growing demand. The research sheds light on the current state of teaching Chinese as a second language (CSL) on the example of International Humanitarian University (Odesa, Ukraine) and shares the experience of technology-assisted curriculum that contributes to the Chinese teaching process. To do that, the paper compares the scores of the students who learn Chinese as a foreign language in experimental (EG) and the control (CG) groups. EG used a number of modern technologies to assist the educational process, while CG used only the traditional teaching approaches. The learning objectives and final test were unbiased and had same tasks for both groups. The results show that $64 \%$ of the students in EG got an A, while just $14 \%$ of those in the CG managed to perform the same. Moreover, the paper presents a SWOT analysis of the use of Edmodo (online educational platform) and some other applications for the teaching and learning foreign languages, namely Quizlet, Kahoot! and Duoliguo for Schools. And the last but not least, the study develops a student-centered model that helps a teacher to assist unlimited number of students and, therefore, minimize the academic expanses and resources on learning activities. The major limitations of the research are related to the small number of participants and insufficient development of the Ukrainian educational system in terms of the implementation of online educational platforms. Further research can focus on the potential ways of using technology-enriched curriculum for maximizing the academic outcomes among CSL students.
\end{abstract}

Keywords: Chinese as a second language learning; educational platforms; technology-enhanced learning environment; Edmodo; Ukrainian educational system.

\section{INTRODUCTION}

The development of digital communication methods, information transfer and social networking had a significant influence on education. The technology development has made it possible for individuals with less computer skills to produce and disseminate information. As a result, learning now can occur almost at any time and in any place that has communication services. Such trends have initiated the boost of new educational paradigms like ubiquitous, seamless, life-long learning and appeared to be extremely helpful for teaching as well [10]. Such a matter of fact is especially true for language acquisition, as it opens new horizons for practical implementation of the skills acquired in formal educational settings.

The statement of problem. Nowadays, Ukraine is rapidly developing its international presence and building up its potential. One of its key partners is China that actively promotes the upbringing of Chinese-speaking professionals under the "One Belt - One Road" initiative [2], [6]. However, despite the rising demand, Ukrainian educational institutions still lack academic staff and resources to teach the constantly growing number of applicants who want to study Chinese. As a result, even those who managed to get enrolled experience difficulties due to the limited attention from the teacher's side and outdated educational materials. Since 
Ahmed and Nasser assure that the application of new technologies has already proved to be effective in teaching foreign languages [3], current research investigates their possible usage for teaching Chinese as a second language (CSL) in Ukrainian realities.

The article's goal is to understand how the implementation of modern technologies to the traditional classroom teaching can assist those who learn Chinese as a second language. The paper demonstrates the example of the new technology-assisted curriculum used in the International Humanitarian University, Odessa and conducts a SWOT analysis of Edmodo educational platform. More importantly, the author adds specific recommendations for the improvement of teaching methodology in terms of student-centered educational approach and gives suggestions on how to guarantee access to high-quality resources to a larger number of students.

\section{THE THEORETICAL BACKGROUNDS}

In order to understand the importance and relevance of the research, one should first investigate the current state of affairs in the technology-enhanced learning and CSL teaching in Ukraine. In this regard, it is crucial to specify the applications and educational platforms that can be used for it.

\subsection{Current state of technology-enhanced learning in Ukraine}

Since literacy and knowledge are the main driving force of the country's development, Ukraine tries to keep up with world trends in terms of education. However, Bykov and Leschenko underline that despite the new governmental policies, it still fails to meet the high standard of the international educational trends, especially in ICT literacy [13]. They assume that the limited use of pedagogical potential is mainly attributed to insufficient awareness of available tools and technologies, as well as to the lack of financial support from the side of institutions [13]. While the second reason is not likely to change in the nearest future, the situation with ICT literacy is improving. Turchyna states that "traditional learning with digital technologies is not a trend but a time requirement" [12, p. 262]. Teachers try to make their curriculum more appealing to students, therefore, motivating them to learn more in their spare time.

The implementation of the modern technologies to the classroom should not only be supported by the teachers and officials, but the students should also accept and get used to the new trends in teaching and learning. Szimkovics and Bujdosó investigated the use of blendedclassrooms in the middle schools of Uzhorod, Ukraine [11]. They have noticed that the students are open to the new technology-enhanced environments and are more interested in learning when the teacher combines traditional and innovative methods [11].

\subsection{Online educational platforms}

Yudina, Shavkun, Dybchynska, and Bukharina focused their attention on the usage of Moodle educational platform in Ukrainian realities [9]. Under the research, they have collected the data from 52 bachelor students in Zaporizhzhya National University (Zaporizhzhya, Ukraine), to see if the technology-enhanced curriculum motivates students to get involved in the educational process [9]. They have found that all participants enjoyed new teaching style, but the main drawback of the research is that it has not covered any information on the teacher's feedback and difficulties associated with the use of Moodle. The latter can be found in the paper written by Marchenko who compared the problems associated with the implementation of Moodle compared to open EdX platforms [5]. The researcher 
sums up that "EdX does less things than Moodle but does them nicely" [5, p. 177]. She underlines that even though the Moodle can be adjusted to any needs of the educational process, it requires huge time, effort and skills to fully use it. Since the platform is overloaded with features, the teachers quite often get confused and are afraid to continue working with the application [1]. As such, it is crucial to find some other educational platform that would have a user-friendly interface.

The current paper analyzes the use of Edmodo educational platform, which is not as complicated as Moodle. In fact, it looks a lot like popular social networking services, for instance Facebook, but has extra features designed for educational purposes. Pokrzycka used it for teaching English as a second language to $\mathrm{BA}$ and $\mathrm{PhD}$ students at Maria CurieSklodowska University (Lublin, Poland) [4]. The study concludes that the Edmodo is a great choice for the higher educational institution as reported by the students and teachers involved in the research [4].

\subsection{CSL in Ukraine}

Currently, Chinese language is getting more and more popular among the Ukrainians of different age and social status. However, the educational system faces the lack of teachers, which, in turns, hinders the learning outcomes of those who study Chinese. As for now, the CSL is officially taught by five Confucius Institutes located in Kharkiv State University, Kyiv State Linguistic University, Luhansk National Pedagogical University, Taras Shevchenko National University of Kyiv and South Ukranian National Pedagogical University. Moreover, students can get enrolled in the BA, MA and PhD programs major in Chinese or apply for different courses offered by private language centers.

It is important to highlight that even though more and more students apply for this subject, the number of Chinese language teachers is still drastically low. For instance, in the International Humanitarian University (Odessa, Ukraine) the number enrolled first-year students was 16 in 2016, 29 in 2017, and raised up to 44 in 2018. However, the university had only 2 Chinese teachers in 2016, 3 in 2017, and 3 in 2018. It is clear that the faculty has to maximize efforts for hiring more staff, but at a time it is crucial to guarantee that the available teachers do their best to work with more students at a time.

\subsection{Research questions}

Current paper aims to answer the following research questions:

1. Can the implementation of technology-enriched curriculum make Chinese language teaching more productive?

2. What are strengths, weaknesses, opportunities and threats of the implementation of online educational platforms (on the example of Edmodo) for enhancing teaching process?

3. How can a student-centered model help a teacher assist unlimited number of students?

\section{RESEARCH METHODS}

\subsection{Research participants}

The research was conducted in the International Humanitarian University (Odessa, Ukraine) and involved two groups of first grade students major in Teaching Chinese as a second language. The participants were randomly divided in the experimental group (EG) and the control one (CG). Since none of the students had previous experience in learning Chinese, 
two groups were considered equal at the start of the experiment. EG consisted of 14 students, while CG comprised 13 members.

\subsection{Research design}

The classes were held 8 times per week and lasted for 80 minutes each. Overall research process lasted a semester and was held from the middle of September 2018 and ended at the beginning of January 2019. According to the requirements of the educational program, at the end of the first semester students were expected to pass HSK 1 level proficiency test, which is equivalent to level A1 of the Common European Framework of Reference for Languages (CEFR).

The groups used different teaching approaches to learn the same amount of the material that was in compliance with the educational curriculum of the institution and met the requirements of academic program. As their primary course materials, CG and EG used first 10 lessons in the textbook called Boya Chinese, Elementary 1, published by Peking University press in 2004. The teacher in CG conducted classed using traditional teaching methods, presenting materials on the blackboard and writing tests on weekly basis. As for the EG, all the materials were given in the online format, through the Edmodo platform. Moreover, the teacher cut down the number of tests to two - mid-term and end-term exams, but asked the students to keep up making online quizzes posted in Edmodo, and other Apps designed for language learning, in particular Duolinguo. Students were encouraged to share their posts on the Discussion Board in Edmodo at least once a week.

Gained knowledge and skills, which are the main dependent variables, were measured twice through the mid- and end-term exams. Students of both groups completed the same test developed by the independent representatives of the Chinese learning center of Odessa Institute of Confucius - to see if there were any differences in the Chinese language proficiency in CG and EG.

In addition, the teacher of the EG shared the vision on a student-centered model that can significantly increase the productivity of the lessons and provides a timely feedback to each student adjusting to his/her personal needs. Such a model may potentially minimize the academic expanses and resources on learning activities. The teacher of the EG also gave valuable advices on how to improve the quality of teaching with the help of modern technologies.

\subsection{Research methods}

To meet the goals stated above, the current research used quantitative data from the test scores. The mean test score results of mid-term and end-term exams were compared to see if there was any significant correlation between the Chinese language proficiency in two groups. Further research is needed to see the readiness of Ukrainian university students to use modern technologies.

\section{THE RESULTS AND DISCUSSION}

\subsection{Research question \#1}

To answer the main research question and see if there is any correlation between the implementation of educational technologies and proficiency in CSL, this case study collected the scores of two tests conducted in the middle and at the end of the semester in both EG and CG. The data is as follows. 
Table 1

Individual progress scale of the students in EG

\begin{tabular}{|c|c|c|}
\hline Student & Mid-term & End-term \\
\hline 1 & $77(\mathrm{C})$ & $92,5(\mathrm{~A})$ \\
\hline 2 & $63,5(\mathrm{E})$ & $60(\mathrm{E})$ \\
\hline 3 & $67(\mathrm{D})$ & $90(\mathrm{~A})$ \\
\hline 4 & $90,5(\mathrm{~A})$ & $100(\mathrm{~A}+)$ \\
\hline 5 & $78(\mathrm{C})$ & $92,5(\mathrm{~A})$ \\
\hline 6 & $76(\mathrm{C})$ & $97,5(\mathrm{~A}+)$ \\
\hline 7 & $71,5(\mathrm{D})$ & $65(\mathrm{E})$ \\
\hline 8 & $75,5(\mathrm{C})$ & $80(\mathrm{C})$ \\
\hline 9 & $73,5(\mathrm{D})$ & $97,5(\mathrm{~A}+)$ \\
\hline 10 & $66(\mathrm{D})$ & $90(\mathrm{~A})$ \\
\hline 11 & $72,5(\mathrm{D})$ & $92,5(\mathrm{~A})$ \\
\hline 12 & $86,5(\mathrm{~B})$ & $87,5(\mathrm{~B})$ \\
\hline 13 & $71,5(\mathrm{D})$ & $90(\mathrm{~A})$ \\
\hline 14 & $60(\mathrm{E})$ & $82,5(\mathrm{~B})$ \\
\hline Average score & $73.5(\mathrm{D})$ & $86.89(\mathrm{~B})$ \\
\hline
\end{tabular}

Table 2

Individual progress scale of the students in CG

\begin{tabular}{|l|l|l|}
\hline Student & Mid-term & End-term \\
\hline 1 & $61(\mathrm{E})$ & $85(\mathrm{~B})$ \\
\hline 2 & $73(\mathrm{D})$ & $82,5(\mathrm{~B})$ \\
\hline 3 & $69(\mathrm{D})$ & $60(\mathrm{E})$ \\
\hline 4 & $60(\mathrm{E})$ & $72,5(\mathrm{D})$ \\
\hline 5 & $74,5(\mathrm{C})$ & $82,5(\mathrm{~B})$ \\
\hline 6 & $66(\mathrm{D})$ & $87,5(\mathrm{~B})$ \\
\hline 7 & $61,5(\mathrm{E})$ & $75(\mathrm{C})$ \\
\hline 8 & $77,5(\mathrm{C})$ & $90(\mathrm{~A})$ \\
\hline 9 & $67(\mathrm{D})$ & $90(\mathrm{~A})$ \\
\hline 10 & $62(\mathrm{E})$ & $65(\mathrm{E})$ \\
\hline 11 & $60(\mathrm{E})$ & $87,5(\mathrm{~B})$ \\
\hline 12 & $60,5(\mathrm{E})$ & $72,5(\mathrm{D})$ \\
\hline 13 & $74,5(\mathrm{D})$ & $77,5(\mathrm{C})$ \\
\hline Average score & $66.65(\mathrm{D})$ & $79.03(\mathrm{C})$ \\
\hline
\end{tabular}

As one can see form Table 1 and 2, the average score of the students in EG is higher both for the mid- and end-term exams. In addition, the Graph 1 below visually demonstrate the deviation the GPA marks according to IHU regulations at the end of the semester. The scores of the final test demonstrate if students were able to meet academic requirements of the program and at what level. One can clearly see that the number of those who have managed to get an $\mathrm{A}$ in the EG is more than four times bigger than that in the CG. 


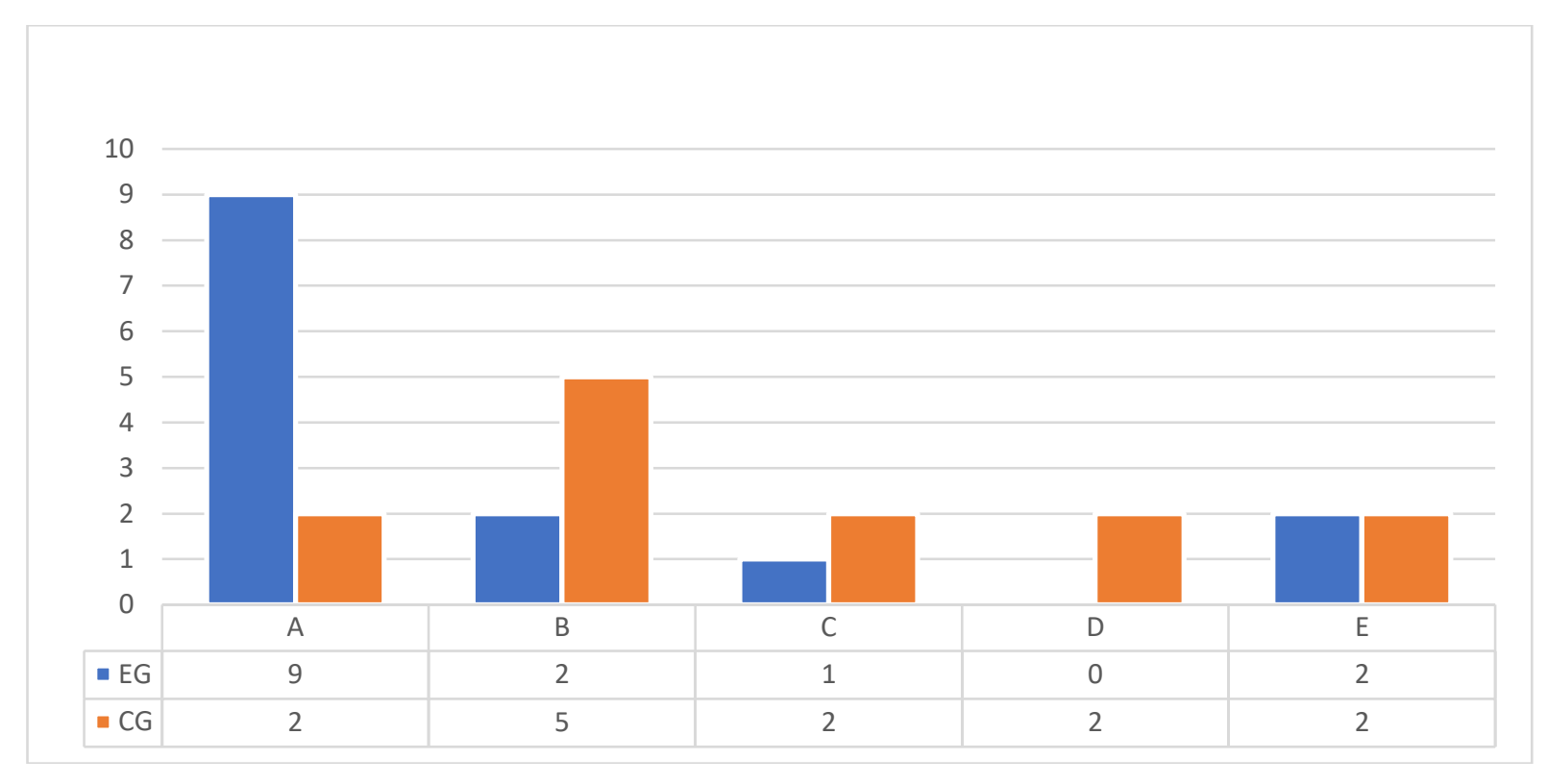

Graph 1. GPA scores

\subsection{Research question \#2}

In addition to quantitative research, the current paper summarized the feedback from the teacher of the EG on the implementation of the educational technology in the teaching and learning process. In particular, the teacher admitted that she has chosen a free online educational platform Edmodo as her main tool for in-class and after-class activities. Sokolyuk has mentioned that Edmodo is highly effective for online communication between teachers and learners [7]. The platform has a wide range of strengths and present many opportunities for the teaching process. However, it also has some weaknesses and its successful implementation to the curriculum of the university may have face different threats. The table 3 provides a SWOT analysis of the Edmodo educational platform based on the teacher's feedback.

Table 3

\section{SWOT analysis of the Edmodo educational platform}

\begin{tabular}{|c|c|}
\hline Strengths & Weaknesses \\
\hline $\begin{array}{l}\checkmark \text { Free online educational platform with user- } \\
\text { friendly interface; } \\
\checkmark \text { Can be used as one platform to meet all } \\
\text { needs of the educational needs of the } \\
\text { institution or of a single teacher; } \\
\checkmark \text { Three types of the user accounts with } \\
\text { different interfaces and roles (teacher, } \\
\text { student, parent); } \\
\checkmark \text { Wide range of features that differs based on } \\
\text { the type of the user account (see table 4); } \\
\checkmark \text { Adjustable timings for posts and } \\
\text { assignments; } \\
\checkmark \text { Mobile App for Android and iOS. }\end{array}$ & $\begin{array}{l}\checkmark \text { Teacher cannot control the amount of time that } \\
\text { student spends online; } \\
\checkmark \text { No ready-made quizzes, tests and learning materials, } \\
\text { the teachers have to do everything on their own or } \\
\text { find it in the other resources; } \\
\checkmark \text { There are no integrated online video-conferencing } \\
\text { tools; } \\
\checkmark \text { Students have no access to the online Gradebook; } \\
\checkmark \text { Interface supports only English language. }\end{array}$ \\
\hline Opportunities & Threats \\
\hline $\begin{array}{l}\checkmark \text { Handles faculty shortage as one teacher can } \\
\text { assist unlimited number of students; } \\
\checkmark \text { Contributes to the flexibility of ubiquitous } \\
\text { education; }\end{array}$ & $\begin{array}{l}\checkmark \text { Teacher cannot control the amount of time that } \\
\text { student spends online; } \\
\checkmark \text { Exchanging IDs and passwords for completing the } \\
\text { assignments; }\end{array}$ \\
\hline
\end{tabular}


$\checkmark$ Increase the overall performance of the learners, as they get timely access to all educational materials

It is worth noting that one of the key strengths of the Edmodo is that is has many unique features that are adjusted to meet the needs of different type of the users. Table 4 illustrates the main functions that can be accessed through the teacher's, student's and parent's account. It is based on the information retrieved from the teacher of the EG.

Table 4

\section{Key functions available for different accounts}

\begin{tabular}{|l|l|l|}
\hline \multicolumn{1}{|c|}{ Teacher } & \multicolumn{1}{c|}{ Student } & \multicolumn{1}{c|}{ Parent } \\
\hline $\begin{array}{l}\text { 1. Share any type of the content, } \\
\text { including links to the external } \\
\text { resources; }\end{array}$ & $\begin{array}{l}\text { 1. Online access to all course } \\
\text { materials; } \\
\text { 2. Assignment list with set } \\
\text { deadlines; }\end{array}$ & $\begin{array}{l}\text { 1. Track child's progress; } \\
\text { 2. Direct online chat with the } \\
\text { teacher. }\end{array}$ \\
$\begin{array}{l}\text { 2. Place assignments with a set deadline; } \\
\text { 3. Online Gradebook with automatic } \\
\text { calculations and options to grant } \\
\text { badges for different achievements; }\end{array}$ & $\begin{array}{l}\text { 3. Instant feedback from the } \\
\text { teacher and peers; } \\
\text { 4ultiple communication } \\
\text { options. }\end{array}$ & \\
$\begin{array}{l}\text { Ability to comment on the submitted } \\
\text { assignments; }\end{array}$ & & \\
$\begin{array}{l}\text { Multiple options for communication } \\
\text { (private group and 1-to-1 chats, } \\
\text { dashboards, news feed) }\end{array}$ & & \\
\hline
\end{tabular}

\subsection{Research question \#3}

Teacher of the EG shares her vision on how modern technologies can help develop a student-centered model that can be further used to assist unlimited number of learners. The respondent admits in modern era the role of the teacher has significantly transformed and now should be more focused on the assistance, guidance and content development, then on the assessment and control. In this section, she shares her mode of teaching Chinese to Grade-1 university students to show the aforementioned role shift. The example would be of a particular interest to the language teachers who can use it as a guideline for creating their own curriculums. The screenshots with comments provided by the teacher are attached for better understanding and visual support. They are taken from different classes earlier taught by the respondent. Names are changed due to privacy issues.

Online dashboard. To start with, teacher uses Edmodo as an online classroom to share all associated course materials, assign tasks and get student's feedback. The screenshots demonstrate that the platform perfectly suits all the requirements of a regular traditional classroom, but just transfers it online (Figure 1). By doing so, it makes learning process ubiquitous and more student-oriented. 

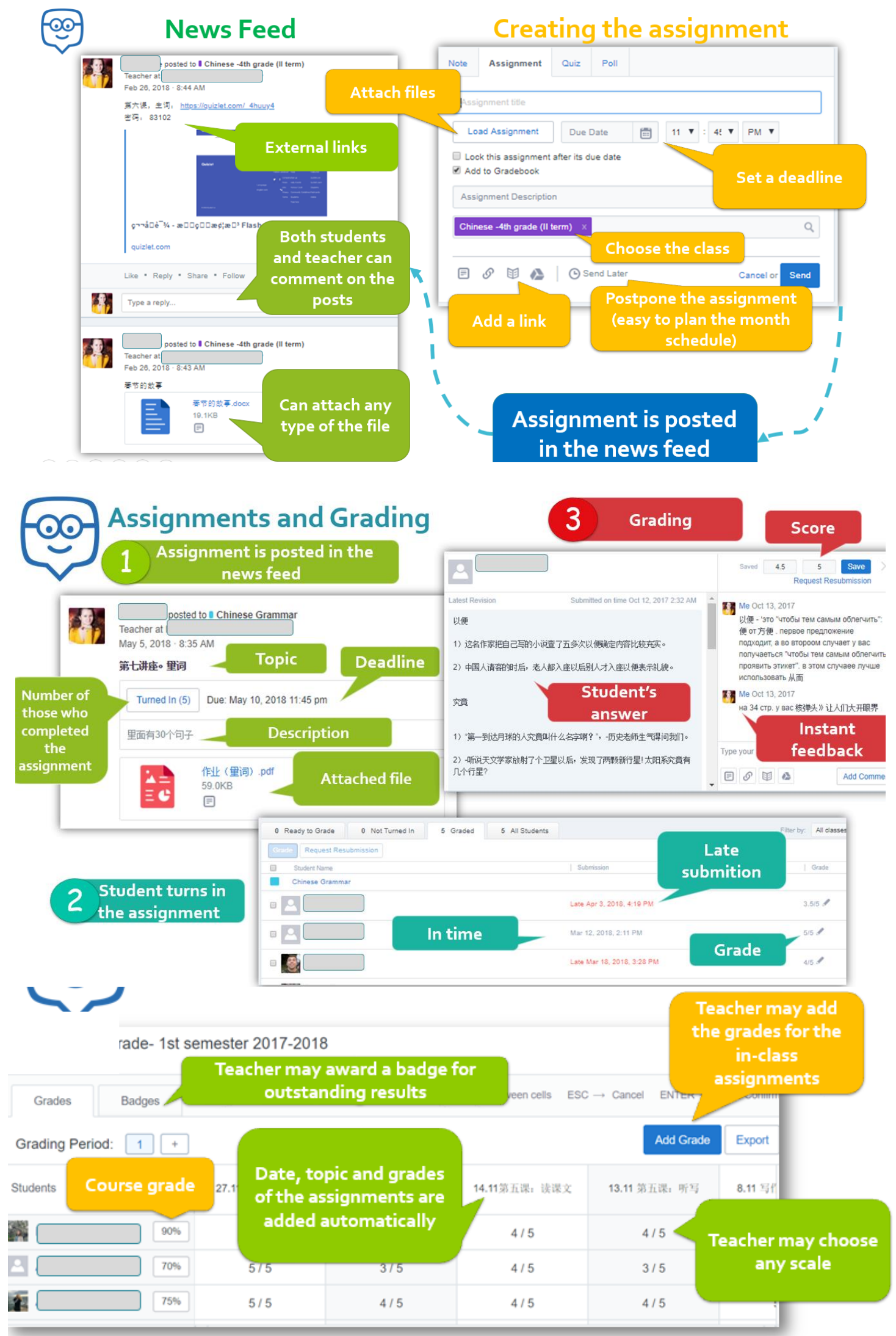

Figure 1. Screenshots that demonstrate the key teaching aspects common for traditional classroom (communicating trough the News Feed; assigning tasks and grading the results) 
Auto-checked quizzes. In order to minimize the time spent on the assessment of the student's assignments and, therefore, maximizing the number of students taught simultaneously, the teacher proposes to create automated online quizzes that are integrated in the platform. The available options include 5 types of the questions, namely multiple choice, true/false, short answer, fill in the blank and matching. One assignment may combine different types of the questions. In that way, the role of the teacher shifts to the curriculum developer who needs to manage the course, create valid content and tasks, but has no longer spend hours on checking the handed-in papers. The quizzes are graded by the platform and the results are automatically transferred to the gradebook (Figure 2). With this feature, a teacher can simultaneously assess unlimited number of students. Moreover, the teacher may check the overall class understanding using the statistics of the correct answers, or analyze the progress of a certain student, as the system allows to see the answers of the selected learner.

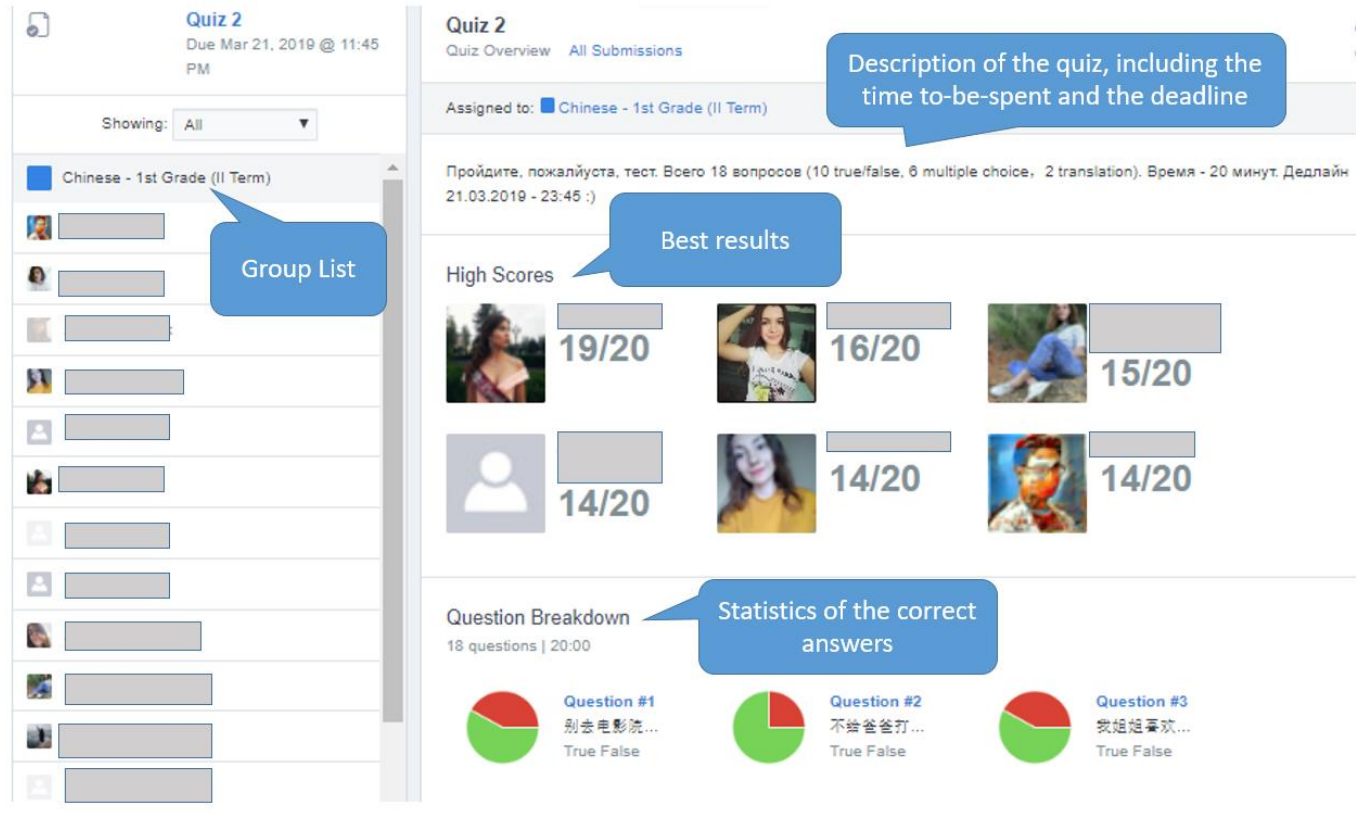

Figure 2. Screenshots that demonstrate the abilities of auto-checked quizzes

Peer-reviewed DBPs. In addition, to minimize the time a teacher spends on grading paper, a respondent advises to use Discussion board posts (DBP) that have to be checked by the peers [5]. Such a system is common in top international universities, but unfortunately is not widely used in Ukraine. Teacher creates the DBP with the assignment and then each student should comment on it. However, each student is responsible for both his-her- own post and the previous one. The teacher may randomly check 3-4 posts a week to mentor the process.

Useful external resources. Among the useful external resources, the respondent mentions massive open online courses (MOOCs) with ready-made materials and integrated grading systems (edX, Udacity, Coursera, TEDx, Prometeus etc.), online classrooms with ready-made content (Duolinguo, LinguaLeo, KhanAcademy among others), online flashcards (Quizlet, Memrize etc.), texting systems (Plickers, Kahoot!, ClassMaker etc.) and visualizing tools (PiktoChart, MindMap, Bibbl.us etc.).

Duolinguo for Schools. When it comes to language education, a particular attention should be paid for the online classrooms with ready-made content. The respondent shared the experience using Duolinguo for schools with the EG. The main advantage of the application 
is that it can be adjusted for both - the needs of the whole class/group and for the personal needs of each student. Duolinguo for schools allows to create two types of the accounts - for teacher and for learner. Through the teacher's account, an instructor may set two types of the goals - personalized (gain experience points) and group (complete an assigned lesson). The teacher can check the results of each student, but all tasks and quizzes are already in the system, which significantly reduces the time spent on the lesson preparation (Figure 3).

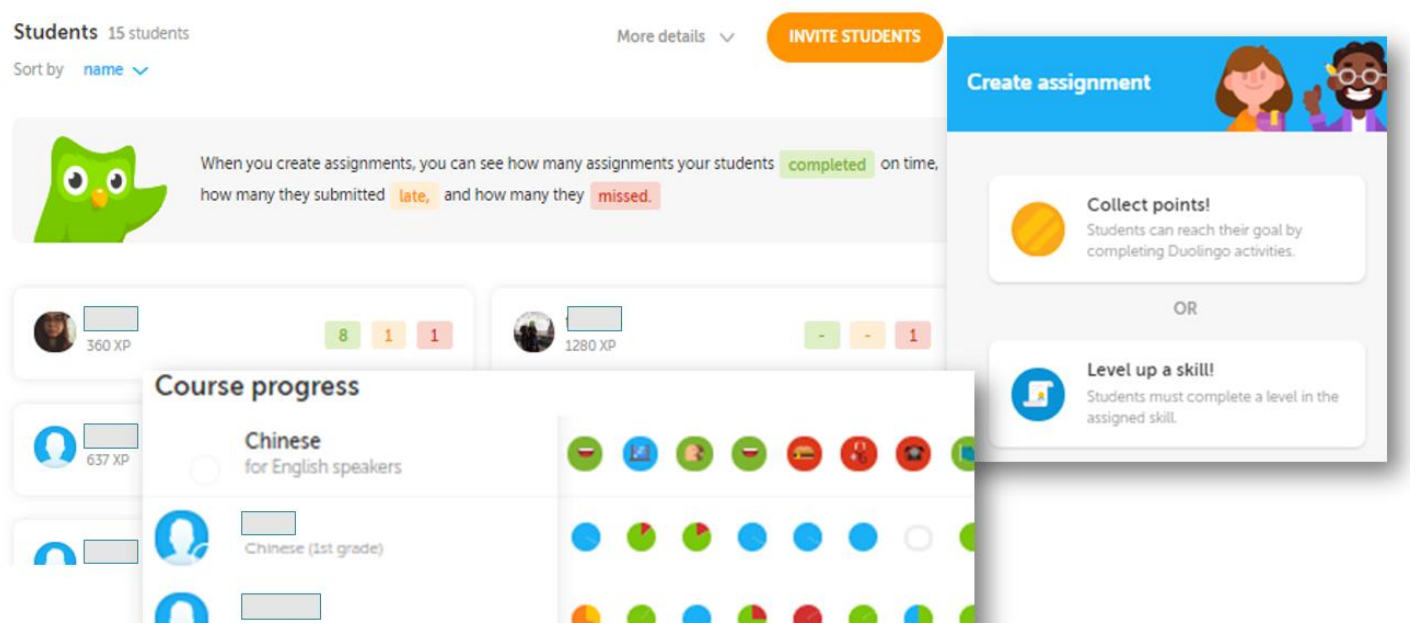

Figure 3. Screenshots that demonstrate the abilities of Duolinguo for Schools

Kahoot! In case the group consists of more than 10 people, it is quite difficult for a teacher to control the in-class work of each student. To make it more fun and engaging, the respondent advises to use Kahoot! The teacher can create a quiz or choose from the available ones and share the code with the students. The learners should choose the correct answers on their devices (smartphones, tablets, PCs) and the teacher instantly gets the class statics. Notably, it can be used for in-class activities (play mode) and as a homework (challenge mode). The platform allows to download the statistics on the student's replies in the Excel format.

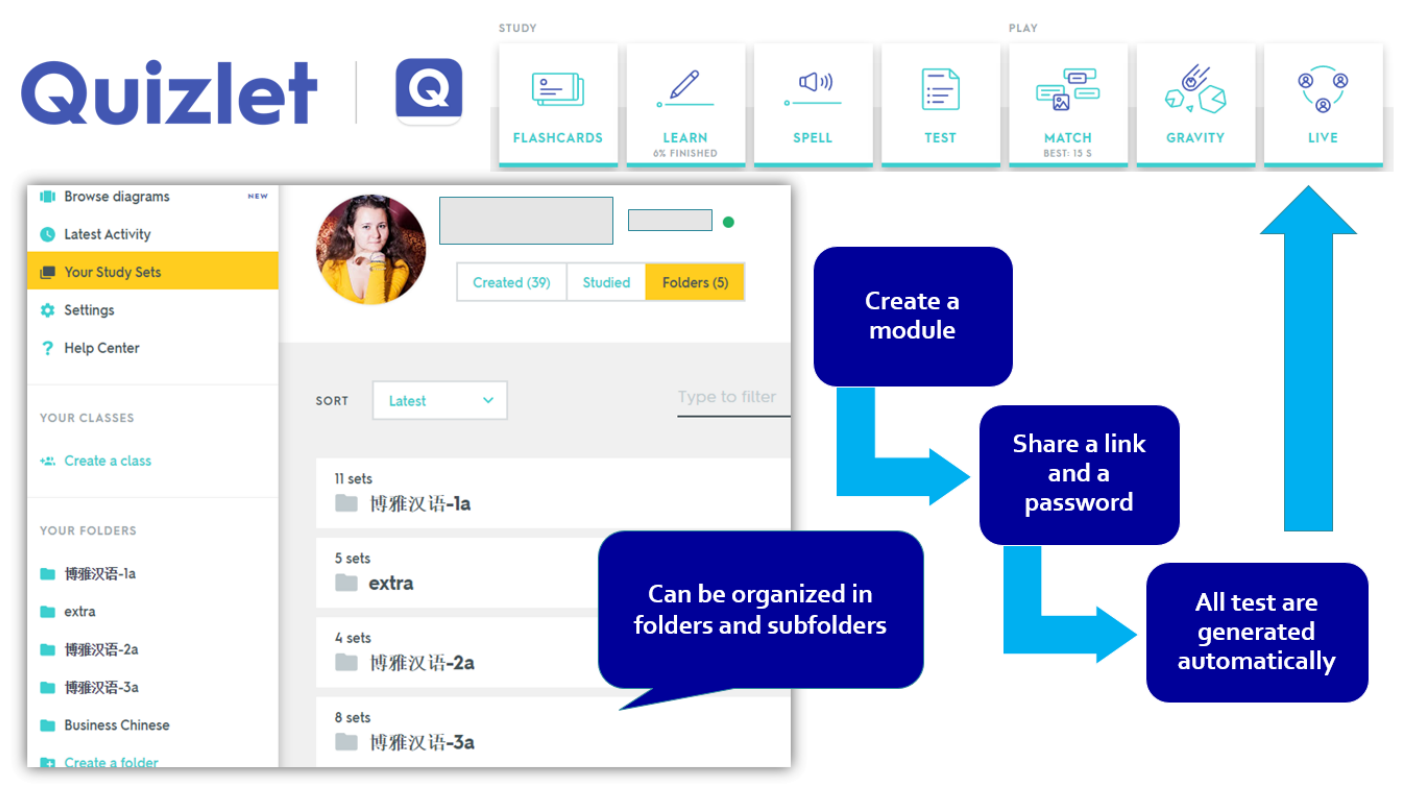

Figure 4. Screenshots that demonstrate the abilities of Quizlet 
Quizlet. Another extremely useful online resource is Quizlet, which can be used for both flashcard sharing and online testing. It allows to create and share personalized modules and works great for memorizing new words in foreign language (Figure 4). In addition, once a teacher added all new words, a program will automatically generate unique tests for each student. Such tests can be used for self-study activities and for the in-class check-ups. Moreover, the system has plenty ready-made sets of the cards, which is useful while preparing for standard language tests, such as IELTS, TOEFL, HSK and others.

\section{CONCLUSION}

In conclusion, the research shows that the implementation of the modern technologies can not only contribute to the learning outcomes, but can deal with the lack of academic staff. In particular, technology-enriched curriculum make Chinese language learning more productive, as $64 \%$ of the students in EG managed to master the course with excellent grades (A/A+), when compared to $14 \%$ of those in the CG. Moreover, the teacher from the EG reported to spent less time on the grading in comparison to the traditional classroom. Though, teachers and institutions can choose from a variety of available online teaching platforms, one of the best options is Edmodo. SWOT analysis has shown that despite few weaknesses and threats, the platform has lots of benefits and opportunities. The platform can be easily personalized to any requirements of the class. Such feathers as online feed, where a teacher can share all relevant resources and initiate peer-reviewed discussions, auto-check quizzes and possibility to insert links to other useful resources (Duolinguo for Schools, Kahoot!, Quizlet etc.) can help teacher assist unlimited number of students at a time.

\section{REFERENCES (TRANSLATED AND TRANSLITERATED)}

[1] F. Ozdamli, E. Ercag, 'Opinions of teacher candidates on the usage of mobile applications in the multimedia development processes', International Journal of Interactive Mobile Technologies, vol. 12, no. 2, pp. 27-38, 2018. (in English)

[2] H. Ma, R. Cai, Y. Ma, 'On the Belt and Road Initiative and Chinese-foreign cooperative orogram', 8th International Conference on Social Science and Education Research (SSER 2018). Atlantis Press, 2018. doi: 10.2991/sser-18.2018.71. (in English)

[3] K. Ahmed, O. Nasser, 'Incorporating iP ad Technology: Creating more effective language classrooms', TESOL Journal, vol. 6, no. 4, pp. 751-765, 2015. doi: 10.1002/tesj.192.(in English)

[4] L. Pokrzycka, 'New methods of teaching in English: Case studies', Bridging Languages and Cultures: Linguistics, Translation Studies and Intercultural Communication, vol. 36, no. 1, pp. 165-169, 2019. (in English)

[5] M. N. AlJeraisy, H. Mohammad, A. Fayyoumi, W. Alrashideh, 'Web 2.0 in education: The impact of discussion board on student performance and satisfaction', Turkish Online Journal of Educational Technology-TOJET, vol. 14, no. 2, pp. 247-258, 2015. (in English)

[6] O. Kratt, K. Pryakhina, M. Bilyk, 'Ukrainian-Chinese collaboration: Prospects of development', SHS Web of Conferences, vol. 39, no.1, pp. 1-9, 2017. doi: 10.1051/shsconf/20173901014.(in English)

[7] O. M. Sokolyuk, 'The problem of assessment of educational process results in an open informationeducational environment for teaching students', Information Technologies and Learning Tools, vol. 57, no. 1, pp 25-37, 2017. (in English)

[8] O. Marchenko, 'Functional comparison of open edx and moodle platforms', Electronic Scientific Professional Journal “Open Educational E-environment of Modern University”, vol. 1, no.1, pp. 171-178, 2015. doi: 10.28925/2414-0325.2015.1.171m8. (in English)

[9] O. Yudina, I. Shavkun, Y. Dybchynska, L. Bukharina, 'ICT using in integrated teaching management core courses in a foreign language', ICTERI, vol. 1, no. 1, pp. 417-428, 2018. (in English)

[10] S. C. Sullivan, J. A. Downey, 'Shifting educational paradigms: From traditional to competency-based education for diverse learners', American Secondary Education, vol. 43, no. 3, pp. 4-19, 2015. (in English)

[11] T. Szimkovics, G. Bujdosó, 'Design informatics special workgroup in view of learner's fields of interest is secondary schools of Transcarpathia', 4th IRI International Educational Conference, Bratislava, 2016. 
doi: 10.18427/iri-2016-0065. (in English)

[12] T. V. Turchyna, 'Advantages of new technologies in teaching foreign languages'. In Quality Language Education in Modern World: Tendencies, Challances, Perspectives (pp. 259-262). Sumy, Ukraine, 2017. (in English)

[13] V. L. Bykov, M. P. Leschenko, 'Digital humanistic pedagogy: Relevant problems of scientific research in the field of using ICT in education'. Informational Technologies and Learning Tools, vol. 53, no. 3, pp. 117, 2016. (in English)

Text of the article was accepted by Editorial Team 01.11.2019

\title{
ВПЛИВ ТЕХНОЛОГІЧНО ОСНАЩЕНОГО НАВЧАЛЬНОГО СЕРЕДОВИЩА НА ВИКЛАДАННЯ КИТАЙСЬКОЇ МОВИ ЯК ІНОЗЕМНОЇ
}

\author{
Далте Ольга Юріївна \\ викладачка кафедри китайської філології, магістр з освітніх технологій \\ Київський національний лінгвістичний університет, м. Київ, Україна \\ ORCID ID 0000-0001-5280-4279 \\ olha.dalte@knlu.edu.ua
}

\begin{abstract}
Анотація. У зв'язку зі зростанням економічних та бізнес-відносин між Україною та Китайською Народною Республікою (КНР) щороку все більше і більше молодих людей починають вивчати китайську мову. Однак на даний момент в українській системі освіти недостатньо економічних ресурсів та академічного персоналу, щоб повністю задовольнити потреби учнів та студентів. Дане дослідження аналізує сучасний стан та тенденції у викладанні китайської як іноземної мови на прикладі Міжнародного гуманітарного університету (м. Одеса, Україна). Крім того, стаття пропонує зразок технологічно оснащеного навчального середовища, що допоможе покращити результати студентів, які вивчають китайську мову, та полегшити навантаження на академічний персонал. Під час дослідження автор порівнює результати тестування 3 китайської мови, яке пройшли студенти експериментальної та контрольної груп. Перша група (експериментальна) активно використовувала новітні інформаційні технології в процесі навчання, тоді як друга (контрольна) навчалась за традиційною системою. Поставлені цілі, навчальні матеріали та тестові задання у двох групах були однакові, відрізнялись лише методи викладання та поточного контролю. Результати дослідження демонструють, що $64 \%$ студентів 3 експериментальної групи отримали «відмінно» на фінальному тестовому завданні, тоді як лише 14\% 3 контрольної групи продемонстрували такі ж досягнення. Крім того, стаття містить SWOT-аналіз онлайн платформи для освітніх цілей Edmodo та деяких інших застосунків для викладання та вивчення іноземних мов, а саме: Quizlet, Kahoot! та Duoliguo for Schools. На додачу стаття пропонує модель навчання, що фокусується на потребах кожного учня та дає можливість учителю одночасно працювати з будь-якою кількістю студентів. Така модель зменшує академічні витрати та ресурси. Основні обмеження даного дослідження пов'язані з відносно невеликою кількістю учасників та недостатнім розвитком інформаційних технологій у сфері освіти в реаліях України. Подальші дослідження мають 3'ясувати найпродуктивніші моделі використання технологічно оснащеного навчального середовища задля забезпечення найкращих академічних результатів серед тих, хто вивчає китайську як іноземну мову.
\end{abstract}

Ключові слова: вивчення китайської як іноземної мови; освітні онлайн платформи; технологічно оснащене навчальне середовище; Edmodo; українська система освіти. 


\title{
ВЛИЯНИЕ ТЕХНОЛОГИЧЕСКИ ОСНАЩЕННОЙ УЧЕБНОЙ СРЕДЫ НА ПРЕПОДАВАНИЕ КИТАЙСКОГО ЯЗЫКА КАК ИНОСТРАННОГО
}

\author{
Далте Ольга Юрьевна \\ преподаватель кафедры китайской филологии, магистр образовательных технологий \\ Киевский национальный лингвистический университет, г. Киев, Украина \\ ORCID ID 0000-0001-5280-4279 \\ olha.dalte@knlu.edu.ua
}

\begin{abstract}
Аннотация. В следствии увеличения количества экономических и бизнес-отношений между Украиной и Китайской Народной Республикой (КНР) с каждым годом все больше и больше людей начинают изучать китайский язык. Однако в данный момент в украинской системе образования недостаточно экономических ресурсов и академического персонала, чтобы полностью удовлетворить нужды учащихся. Данное исследование анализирует современное состояние и тенденции в преподавание китайского як иностранного языка на примере Международного гуманитарного университета (г. Одесса, Украина). Кроме этого, статья предлагает образец технологически оснащенной учебной среды, которая дает возможность улучшить академические результаты студентов, изучающих китайский язык, и уменьшить нагрузку на академический персонал. В ходе исследования автор сравнивает результаты тестирования по китайскому языку, которое прошли студенты экспериментальной и контрольной групп. Первая группа (экспериментальная) активно использовала современные информационные технологии в процессе обучения, тогда как вторая (контрольная) обучалась по традиционной системе. Поставленные цели, учебные материалы и финальный тестовый контроль в двух группах были одинаковыми, отличались лишь методы преподавания и виды текущего контроля. Результаты исследования демонстрируют, что 64\% студентов из экспериментальной группы получили «отлично» на финальном тестовом контроле, тогда как только 14\% участников контрольной группы показали такие же достижения. Кроме этого, статья предоставляет SWOT-анализ онлайн платформы для образовательных целей Edmodo и некоторых других приложений для преподавания и изучения иностранных языков, а именно: Quizlet, Kahoot! и Duoliguo for Schools. Вдобавок статья предлагает пример модели обучения, которая концентрируется на потребностях каждого ученика и позволяет преподавателю одновременно работать с любым количеством студентов. Такая модель уменьшает академические затраты и ресурсы. Основные ограничения данного исследования связаны со сравнительно небольшим количеством участников эксперимента и недостаточным развитием информационных технологий в сфере образования в реалиях Украины. Последующие исследования должны определить самые продуктивные модели использования технологически оснащенной учебной среды для обеспечения наилучших академических результатов среди тех, кто изучает китайский как иностранный язык.
\end{abstract}

Ключевые слова: изучение китайского как второго иностранного языка; образовательные онлайн платформы; технологически оснащенная учебная среда; Edmodo; украинская система образования.

\section{(cc) BY-NC-SA}

ThisworkislicensedunderCreativeCommonsAttribution-NonCommercial-ShareAlike 4.0 InternationalLicense. 